\title{
Meningkatkan Semangat Siswa Pada Pembelajaran IPA Melalui Multimedia Interaktif Berorientasi Pendekatan Kontekstual Materi Sumber Energi Kelas IV SD
}

\section{Made Juana Putra ${ }^{1}$, I Komang Ngurah Wiyasa ${ }^{2}$}

1,2 Program Studi Pendidikan Guru Sekolah Dasar, Universitas Pendidikan Ganesha, Singaraja, Indonesia

\section{ART I C L E IN F O}

Article history:

Received 03 April 2021

Revised 30 April 2021

Accepted 12 Mei 2021

Available online 25 Juni 2021

\section{Kata Kunci:}

multimedia interaktif, IPA

kontekstual

Keywords:

Interactive multimedia, science, contextual

\begin{abstract}
A B S T R A K
Kurangnya media pembelajaran yang mendukung proses pembelajaran di kelas menyebabkan rendahnya motivasi dan hasil belajar siswa. Tujuan dari penelitian ini adalah menciptakan multimedia interaktif berorientasi pendekatan kontekstual materi sumber energi pada pembelajaran IPA. Subjek uji coba penelitian meliputi 1 orang ahli isi pembelajaran, 1 orang ahli desain pembelajaran, 1 orang ahli media pembelajaran dan 15 siswa. Jenis penelitian ini yaitu pengembangan yang berpedoman pada model DDD-E (Decide, Design, Develop, \& Evaulate). Data dikumpulkan menggunakan metode observasi, angket dan wawancara tak terstruktur. Instrument yang digunakan untuk mengumpulkan data yaitu kuesioner. Analisis data menggunakan teknik analisis data deskriptif kualitatif dan teknik analisis data kuantitatif. Hasil review ahli isi menunjukkan multimedia ini berkualifikasi sangat baik
\end{abstract} $(94,50 \%)$, Hasil review ahli desain pembelajaran menunjukkan multimedia ini berkualifikasi sangat baik (94,23\%), hasil review ahli media menunjukkan multimedia ini berkualifikasi sangat baik $(97,65 \%)$, Hasil uji coba perorangan memperoleh skor (93,33\%) (kualifikasi sangat baik), dan hasil uji coba kelompok kecil memperoleh skor (93,50\%) (kualifikasi sangat baik). Jadi multimedia interaktif layak digunakan dalam pembelajaran IPA di kelas IV SD. Implikasi dari penelitian ini yaitu penggunaan multimedia interaktif mampu meningkatkan motivasi belajar siswa.

\section{A B S T R A C T}

The lack of learning media that supports the learning process in the classroom causes low motivation and student learning outcomes. The purpose of this research is to create interactive multimediaoriented contextual approach to energy source material in science learning. The subjects of the research trial included 1 learning content expert, 1 learning design expert, 1 learning media expert and 15 students. This type of research is development based on the DDD-E model (Decide, Design, Develop, \& Evaulate). Data were collected using the method of observation, questionnaires and unstructured interviews. The instrument used to collect data is a questionnaire. Data analysis used descriptive qualitative data analysis techniques and quantitative data analysis techniques. The results of the content expert review show that this multimedia has very good qualifications (94.50\%), the results of the learning design expert review show that this multimedia has very good qualifications (94.23\%), the results of the media expert review show that this multimedia has very good qualifications (97.65\%), The results of the individual trial obtained a score of (93.33\%) (very good qualification), and the results of the small group trial obtained a score (93.50\%) (very good qualification). So interactive multimedia is suitable for use in science learning in fourth grade elementary school. The implication of this research is that the use of interactive multimedia can increase students' learning motivation.

\section{Pendahuluan}

Perkembangan IPTEK menuntut bangsa Indonesia untuk meningkatkan kualitas terutama dalam dunia pendidikan. Pendidikan yang berkualitas akan mendukung terciptanya peserta didik yang cerdas serta mampu bersaing di era globalisasi (Fitriyani, Fauzi, \& Sari, 2020; Maunah, 2015; Towoliu, Hartati, \&

Copyright (C) Universitas Pendidikan Ganesha. All rights reserved 
Hapidin, 2020). Namun nyatanya saat ini kondisi pendidikan di Indonesia sedang tidak baik. Hal ini disebabkan oleh wabah Covid-19. WHO mengumumkan bahwa virus ini penularannya sangat cepat dan dapat menyebabkan kematian. Wabah covid-19 menyebabkan perubahan terhadap pelaksanaan proses pembelajaran tatap muka menjadi pembelajaran berbasis daring (Herliandry, Enjelina, \& Kuswanto, 2020). Kondisi seperti ini mengharuskan guru untuk mengganti pembelajaran tatap muka dengan $E$ learning atau melalui media online lainnya (Mustikaningrum, Pramusinta, Ayu, \& Umar, 2020; Qazi et al., 2021). Berbagai platform digunakan untuk melakukan pengajaran sehingga perlu didukung dengan fasilitas pembelajaran yang baik dan pemanfaatan teknologi informasi yang optimal (Asmuni, 2020; Chang et al., 2020). Pelaksanaan pembelajaran daring menimbulkan suatu permasalahan pada pembelajaran IPA. Hal ini disebabkan karena mata pelajaran IPA adalah pembelajaran yang mengandung konsep abstrak dan kejadian konktret yang memerlukan observasi. Pelaksanaan pembelajaran IPA secara daring pada materi sumber energi di kelas IV SD N 5 Abiansemal, hanya dilakukan dengan cara guru memberikan materi yang dikirimkan ke grup kelas dengan menggunakan media online dan dibantu oleh media pembelajaran berupa video pembelajaran yang diambil melalui youtube. Pemberian materi yang monoton mengakibatkan siswa tidak antusias dalam belajar. Berdasarkan hasil observasi ditemukan bahwa guru mengalami kendala dalam penyampain materi sumber energi pada siswa saat pembelajaran daring. Oleh karena itu diperlukan media pembelajaran lain yang dapat membawa siswa ke situasi konkret. Sedangkan guru memiliki waktu yang sangat terbatas untuk membuat media pembelajaran.

Berdasarkan permasalahan tersebut maka guru perlu berinovasi dalam pembelajaran terutama inovasi dalam penggunaan media pembelajaran yang menarik. Salah satunya inovasi yang dapat dilakukan yaitu menciptakan multimedia pembelajaran interaktif. Multimedia interaktif adalah suatu tampilan multimedia yang dirancang oleh desainer agar tampilannya memenuhi fungsi menginformasikan pesan dan memiliki interaktifitas kepada pengguna (Heo \& Toomey, 2020; Wulandari, Susilo, \& Kuswandi, 2017). Kegiatan pembelajaran dengan multimedia dapat memberikan pengalaman konkret pada siswa. Multimedia interaktif yang diharapkan adalah multimedia interaktif yang menarik minat siswa dan memberikan pemberahuan dalam proses pembelajaran (Diputra, 2016; Maria, Rusilowati, \& Hardyanto, 2019; Surjono, 2016). Selain itu, didalam multimedia interaktif harus tercantumkan KI dan KD yang akan dicapai dalam pembelajaran (Prasetya, el at. 2018). Multimedia interaktif berisikan materi, contoh, dan soal atau permainan yang menunjang pemahaman siswa. Untuk mengoptimalkan multimedia interaktif untuk anak-anak usia sekolah dasar maka harus dilengkapi dengan lagu anak-anak yang sesuai dengan jenjang usianya akan membuat siswa lebih nyaman dalam belajar. Tampilan warna dan gambar sesuai dengan tingkat perkembangan siswa akan mendukung antusias siswa dalam belajar serta membantu dalam hal memahami materi yang diberikan. Dengan adanya media pembelajaran maka posisi guru bukan lagi sebagai satu-satunya sumber belajar, melainkan sebagai fasilitator (Campen et al, 2020; Pravitasari \& Yulianto, 2018).

Media dapat bermanfaat dalam mengatasi keterbatasan pengalaman yang dimiliki oleh para siswa. Selain itu media juga dapat mengkongkretkan konsep-konsep yang abstrak, media pemebelajaran dapat mengatasi keterbatasan indera, ruang, dan waktu, memungkinkan adanya interaksi langsung antara siswa dan lingkungannya, membangkitkan motivasi dan rangsangan anak untuk belajar serta memberikan pengalaman yang integral atau menyeluruh dari konktret sampai hal yang bersifat abstrak (Nataliani, Jampel, \& Suartama, 2014; Saselah, M, \& Qadar, 2017). Pada sekolah dasar pembelajaran IPA merupakan pembelajaran yang sulit untuk dipahami karena memerlukan beberapa kali penjelasan dan contoh untuk memahaminya (Kurniawati, Sudana, \& Mahadewi, 2013; Permana \& Nourmavita, 2017). Untuk mengefektifkan penyampaian materi kepada siswa, multimedia interaktif mengadaptasi pendekatan pembelajaran yang tepat sehingga beranfaat secara optimal. Oleh sebab itu dalam mengembangkan multimedia interaktif, diperlukan pendekatan kontekstual yang dapat memberikan pengalaman konkret pada siswa (Buchori, 2019). Pendekatan kontekstual merupakan suatu konsep belajar yang membantu guru untuk menghadirnya situasi nyata ke dalam proses pembelajaran di kelas serta membantu siswa untuk menghubungkan pengetahuannya dengan implementasi di kehidupan bermasyarakat (Latief, 2014; Mariyaningsih, 2012; Santoso, 2017). Melaui pendekatan kontekstual ini, siswa akan belajar lebih baik dan lebih bermakna jika siswa menemukan dan mengalami sediri apa yang dipelajarinya, bukan sekedar mengetahuinya (Andrianingrum \& Suparman, 2019; Gitriani, Aisah, Hendriana, \& Herdiman, 2018; Nilasari, Djatmika, \& Santoso, 2016). Pendekatan kontekstual dapat mendorong siswa berperan aktif dalam kegiatan pembelajaran, baik yang dilakukan secara mandiri maupun berkelompok. Hal ini memungkinkan siswa untuk menghubungkan ini materi dengan kehidupan sehari-hari, sehingga proses pembelajaran IPA terpusat pada siswa (student centered learning) (Hobri, Septiawati, \& Prihandoko, 2018).

Temuan penelitian sebelumnya manyatakan bahwa bahwa penggunaan multimedia interaktif dalam proses pembelajaran dapat menarik perhatian siswa dan menimbulkan rasa senang dalam 
mengikuti pembelajaran yang berujung pada peningkatan hasil belajar siswa (Istiqlal, 2017; Mawarni \& Muhtadi, 2017; Yuniarni, Sari, \& Atiq, 2020). Temuan penelitian sebelumnya juga menyatakan bahwa penggunaan multimedia interaktif dapat memotivasi siswa untuk belajar dan memudahkan guru untuk menyampaikan materi (Irwanto, Taufik, Hernawan, \& Rizal, 2019; Ratih, Japa, \& Margunayasa, 2017). Dapat disimpulkan bahwa multimedia interaktif dapat membantu siswa dalam belajar. Kelebihan media yang akan dikembangkan yaitu media ini berisikan contoh yang mudah ditemukan pada kehidupan seharihari siswa sehingga siswa dapat memahami materi pembelajaran dengan mudah. Multimedia interaktif dipilih karena dapat menjelaskan suatu konsep materi yang bersifat abstrak menjadi lebih konkret, serta dapat menjadikan pembelajaran lebih menarik, lebih interaktif, dan lebih berkualitas. Belum adanya kajian mengenai multimedia interaktif berorientasi pendekatan kontekstual pada materi sumber energi untuk kelas IV SD. Penelitian ini bertujuan untuk menciptakan multimedia interaktif berorientasi pendekatan kontekstual pada materi sumber energi untuk kelas IV SD. Diharapkan media yang akan dikembangkan ini dapat membangkitnya motivasi siswa dalam belajar sehingga berdampak pada hasil belajar IPA pada siswa meningkat.

\section{Metode}

Jenis penelitian ini adalah penelitian dan pengembangan atau research and development (R\&D). Penelitian pengembangan ini dilaksanakan pada siswa kelas IV SD Nomor 5 Abiansemal. Subjek pada penelitian ini yaitu ahli isi pembelajaran, ahli desain pembelajaran, ahli media pembelajaran, 3 siswa untuk uji coba perorangan, dan 12 siswa untuk uji coba kelompok kecil. Prosedur pengembangan yang digunakan dalam penelitian ini mengacu pada model pengembangan yang digunakan, yaitu model pengembangan DDD-E (Decide, Design, Develop, Evaluate) yang memiliki 4 tahap yaitu: (1) tahap menetapkan (decide), (2) tahap desain (desain), (3) tahap mengembangkan (develop), (4) tahap mengevaluasi (evaluate). Pemilihan model DDD-E dalam mengembangkan multimedia interaktif ini dikarenakan model DDD-E merupakan model pengembangan yang sederhana namun memiliki tahapan pengembangan yang sistematis, jelas, dan mudah. Selain itu model pengembangan ini memberikan kesempatan kepada pengembang untuk melakukan evaluasi dan revisi scara terus menerus dalam setiap fase yang dilalui untuk menyempurnakan produk berupa multimedia interaktif. Sehingga diharapkan mampu menunjang proses pembelajaran sehingga tujuan pembelajaran dapat tercapai. Pada penelitian pengembangan ini data diperoleh dengan menggunakan metode observasi, wawancara dan penyebaran kuesioner pada subjek penelitian. Instrumen yang digunakan yaitu lembar pencatatan dan lembar kuesioner. Hasil dari lembar pencatatan diolah menjadi laporan pengembangan produk multimedia interaktif secara ringkas. Lembar kuesioner pada penelitian ini digunakan untuk mengukur validitas produk yang dikembangkan dari hasil review ahli isi pembelajaran, ahli media pembelajaran, ahli desain pembelajaran, dan tanggapan siswa saat uji coba perorangan, dan kelompok kecil. Adapun kisi-kisi instrumen kuesioner validitas multimedia pembelajaran interaktif dapat disajikan pada tabel sebagai berikut.

Tabel 1. Kisi-kisi Instrumen Ahli Isi Pembelajaran

\begin{tabular}{|c|c|c|}
\hline No & Aspek & Indikator \\
\hline 1 & Kurikulum & $\begin{array}{ll}\text { a. Kesesuaian kompetensi dasar } \\
\text { b. Indokator } \\
\text { c. Tujuan pembelajaran }\end{array}$ \\
\hline 2 & Materi & $\begin{array}{l}\text { a. Kejelasan materi } \\
\text { b. Didukung media yang tepat }\end{array}$ \\
\hline 3 & Bahasa & $\begin{array}{l}\text { a. Pengunaan bahasa yang tepat } \\
\text { b. Bahasa sesuai dengan karakteristik siswa }\end{array}$ \\
\hline
\end{tabular}

Tabel 2. Kisi-kisi Instrumen Ahli Desain Pembelajaran

\begin{tabular}{cccl}
\hline No & Aspek & & \multicolumn{1}{c}{ Indikator } \\
\hline $\mathbf{1}$ & Tujuan & a. & Kejelasan tujuan pebelajaran \\
& & b. & Kesesuaian tujuan dengan materi \\
$\mathbf{2}$ & \multirow{2}{*}{ Strategi } & a. & Penyampaian materi \\
& & b. & Pemberian contoh \\
$\mathbf{3}$ & \multirow{2}{*}{ Evaluasi } & a. & Penyajian soal \\
& & b. & Petunjuk soal \\
& & c. & Pemberian umpan balik \\
\hline
\end{tabular}


Tabel 3. Kisi-kisi Instrumen Ahli Media Pembelajaran

\begin{tabular}{llll}
\hline No & \multicolumn{1}{c}{ Aspek } & & \\
\hline \multirow{4}{*}{ Desain } & a. & Teks \\
& & b. Gambar \\
& & c. & Indikator \\
\hline \multirow{2}{*}{$\mathbf{2}$} & Pengoperasian & d. Animasi \\
& & e. Suara dan Video \\
& & a. & Petunjuk pengunaan multimedia \\
& & b. & Multimedia mudah digunakan \\
\hline
\end{tabular}

Tabel 4. Kisi-kisi Instrumen Uji Coba Perorangan dan Kelompok Kecil

\begin{tabular}{|c|c|c|}
\hline No & Aspek & Indikator \\
\hline 1 & Desain & $\begin{array}{ll}\text { a. } & \text { Kemenarikan desai produk } \\
\text { b. } & \text { Keterbacaan teks } \\
\text { c. } & \text { Kejelasan gambar }\end{array}$ \\
\hline 2 & Materi & $\begin{array}{l}\text { a. Kemudahan pemahaman materi } \\
\text { b. Kejelasan materi }\end{array}$ \\
\hline 3 & Pengoperasian & a. Kemudahan pengoperasian \\
\hline 4 & Motivasi & a. Media memberikan semangat belajar \\
\hline
\end{tabular}

Teknik analisis data yang digunakan pada penelitian pengembangan ini adalah teknik analisis deskriptif kualitatif, dan teknik analisis deskriptif kuantitatif. Pada penelitian pengembangan ini, teknik analisis deskriptif kualitatif digunakan untuk mengolah data berupa masukan, komentar, ataupun saran dari para ahli pada uji validitas produk, dan siswa pada uji coba perorangan dan kelompok kecil. Pada penelitian pengembangan ini, teknik analisis deskriptif kuantitatif digunakan untuk mengolah data hasil penelitian yang diperoleh melalui angket dalam bentuk skor. Untuk dapat memberikan makna dalam pengambilan keputusan, maka digunakan ketetapan konversi tingkat pencapaian dengan skala 5.

\section{Hasil dan Pembahasan}

Hasil penelitian ini berupa Multimedia interaktif, rancangan multimedia interaktif ini menggunakan model pengembangan DDD-E yang terdiri dari emapt fase atau tahapan pengembangan. Tahap pertama yang dilakukan yaitu tahap menetapkan (decide). Pada tahap ini dilakukan tahap untuk merencanakan produk multimedia interaktfi melalui hasil observasi dan wawancara guru wali kelas untuk mengetahui kebutuhan dari peserta didik. Tahap kedua yaitu desain (design), pada tahap ini dilakukan mendesain media yang akan dikembangkan yaitu meliputi membuat outline content, pembuatan flowcart, pembuatan storyboard, medisain tampilan awal, perancangan intrumen penilaian, dan menyusun RPP. Pada pembuatan flowchart dan storyboard sebagai dasar dan alur yang dipakai pada tahap pengembangan, serta pemilihan software yang digunakan dalam mengembangkan multimedia interaktif. Adapun Software yang digunakan yaitu Articulate Storyline 3 sebagai software utama dan dibantu dengan beberapa aplikasi/software lainnya untuk mendesain gambar, membuat animasi, mengedit video, dan mengedit audio. Aplikasi lainnya yang dimaksud adalah Microsoft Word 2013, Adobe Photoshop CC 2018, dan Wondershare Filmora 9. Tahap ketiga yaitu pengembangan (development), pada tahap ini kegiatan yang dilakukan yaitu mengembangkan produk yang sudah direncanakan dan didesain menjadi produk nyata sesuai dengan rancangan flowchart dan storyboard dan dikembangkan menggunakan software yang telah ditentukan. Adapun hasil pengembangan multimedia interaktif disajikan pada gambar 1 .
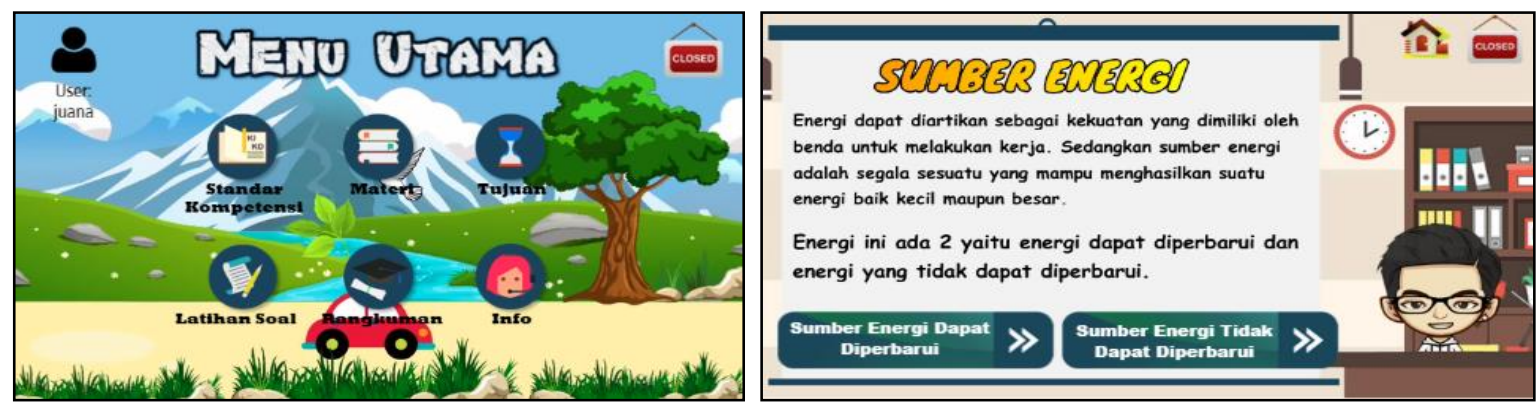

Gambar 1. Multimedia Interaktif Pendekatan Kontekstual 
Setelah media dikembangkan selanjutnya media akan diuji validiasnya oleh ahli isi pembelajaran, ahli desain pembelajaran, ahli media pembelajaran, uji coba perorangan, dan uji coba kelompok kecil. Hasil dari validitas para ahli akan dijadikan acuan untuk evaluasi dan revisi multimedi interaktif demi perbaikan produk yang dihasilkan. Hasil validitas multimedia interaktif ini ditentukan berdasarkan hasil evaluasi oleh ahli isi pembelajaran, ahli desain pembelajaran, ahli media pembelajaran, dan siswa melalui uji coba perorangan dan uji coba kelompok kecil. Data hasil evaluasi dari para ahli dan subjek uji coba produk diolah secara deskriptif dengan mencari perolehan skor rata-rata. Secara lebih rinci, hasil validitas multimedia interaktif dapat disajikan pada tabel sebagai berikut.

Tabel 6. Hasil Uji Validitas Produk

\begin{tabular}{clcc}
\hline No & Subjek Uji Coba Multimedia Interaktif & Hasil Validitas (\%) & Keterangan \\
\hline 1. & Uji Ahli Isi Pembelajaran & $94,50 \%$ & Sangat Baik \\
2. & Uji Ahli Desain Pembelajaran & $94,23 \%$ & Sangat Baik \\
3. & Uji Ahli Media Pembelajaran & $91,17 \%$ & Sangat Baik \\
4. & Uji Coba Perorangan & $93,33 \%$ & Sangat Baik \\
5. & Uji Coba Kelompok Kecil & $93,50 \%$ & Sangat Baik \\
\hline
\end{tabular}

Berdasarkan penilaian yang diberikan oleh ahli isi pelajaran, multimedia interaktif yang dikembangkan mendapatkan nilai 94,50\% sehingga mendapatkan kategori sangat baik. Hasil penilaian yang diberikan oleh ahli desain pembelajaran, multimedia interaktif yang dikembangkan mendapatkan nilai 94,23\% sehingga mendapatkan kategori sangat baik. Hasil penilaian yang diberikan oleh ahli media pembelajaran, multimedia interaktif yang dikembangkan mendapatkan nilai 91,17\% sehingga mendapatkan kategori sangat baik. Berdasarkan hasil uji coba perorangan media yang dikembangkan mendapatkan nilai 93,33\% sehingga mendapatkan kategori sangat baik. Hasil uji coba kelompok kecil media yang dikembangkan mendapatkan nilai 93,50\% sehingga mendapatkan kategori sangat baik. Melalui hasil uji validitas produk diperoleh masukan, saran, dan komentar yang diberikan oleh para ahli dan subjek uji coba produk. Masukan, saran dan komentar tersebut selanjutnya dijadikan sebagai dasar dalam melakukan perbaikan atau revisi produk demi kesempurnaan produk yang dikembangkan. adapun hasil revision produk disajikan pada gambar 2 .
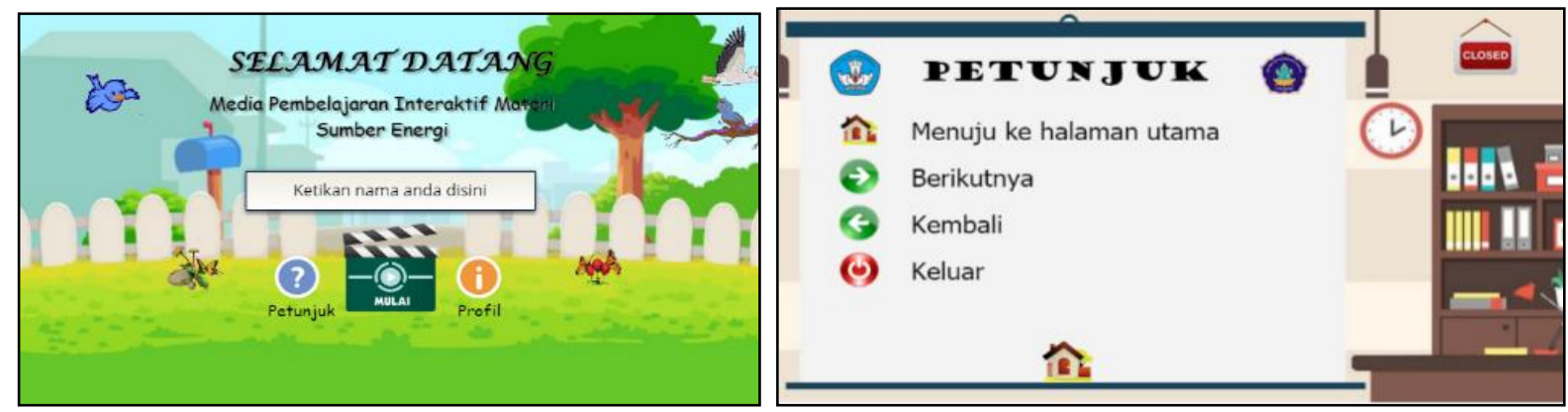

Gambar 2. Revisi Produk Multimedia Interaktif Pendekatan Kontekstual

Hasil uji validitas produk yang dilakukan menunjukkan multimedia interaktif yang dikembangkan dinyatakan valid dengan kualitas sangat baik dan layak digunakan untuk membantu siswa kelas IV dalam belajar pada pembelajaran IPA materi sumber energi dan membantu guru dalam memfasilitasi pembelajaran di SD N 5 Abiansemal. Multimedia interaktif pendekatan kontekstual layak diterapkan dalam proses pembelajaran disebabkan oleh beberapa faktor yaitu sebagai berikut. Ditinjau dari aspek isi pembelajaran, multimedia interaktif berorietasi pendekatan kontekstual ini berada pada kualifikasi sangat baik. Perolehan kualifikasi sangat baik pada aspek isi pembelajaran dipengaruhi oleh kesesuaian materi dengan kompetensi dasar, indikator dan tujuan pembelajaran. Kompetensi dasar merupakan sesuatu yang harus dikuasai atau dicapai oleh siswa. Pencapaian kompetensi dasar dapat dilakukan dengan merumuskan indikator yang dapat diukur sesuai dengan KD dan tujuan pembelajaran (Hartini, 2017; Prayito, 2011). Oleh sebab itu multimedia inetraktif yang baik adalah multi media yang memuat materi yang sesuai dengan KD, indikator, dan tujuan pembelajaran. Dalam menilai aspek isi/materi multimedia interaktif dalam pembelajaran perlu memperhatikan kesesuaian antara isi materi dengan tujuan pembelajaran yang dituntut tercapai oleh siswa, karena elemen tersebut saling berkaitan satu sama lain untuk dapat menciptakan bahan ajar yang baik (Istiqlal, 2017; Mawarni \& Muhtadi, 2017).

Ditinjau dari aspek desain pembelajaran, multimedia interaktif berorientasi pendekatan kontekstual ini berada pada kualifikasi sangat baik dikarenakan multimedia interaktif yang 
dikembangkan dapat memotivasi siswa dalam belajar dan dapat mempermudah siswa dalam memahami materi. Media pembelajaran sebagai salah satu komponen dalam sistem pembelajaran dapat memudahkan siswa memahami materi yang disajikan apabila media tersebut menarik dan mudah digunakan. Media yang dapat digunakan secara langsung oleh siswa akan memberikan kesan pembelajaran yang lebih aktif dan bermakna (Lestari, Putra, \& Negara, 2018; Mustika \& Ain, 2020; Umbara, Sujana, \& Negara, 2020). Disamping itu, multimedia interaktif ini dikembangkan berorientasi pada pendekatan kontekstual. Nilai-nilai pendeketan kontekstual pada multimedia interaktif bertujuan untuk menjadikan pembelajaran menjadi lebih menarik dan bermakna bagi siswa (Puryadi, Rahayu, \& Sutrio, 2018; Rahmawati, Irdamurni, \& Amini, 2019). Melalui pembelajaran kontekstual materi pembelajaran dikaitkan dengan situasi nyata dapat mendorong siswa untuk menghubungkan pengetahuan yang dimiliki dan penerapnnya ke dalam kehidupan sehari-hari. Komalasari (2017) menyatakan bahwa pembelajaran kontekstual adalah suatu pendekatan pembelajaran yang mengkaitkan antara materi yang dipelajari dengan kehidupan nyata siswa sehari-hari dengan tujuan untuk menemukan makna dari materi tersebut bagi kehidupannya sehingga berdampak pada peningkatan hasil belajarnya. Penggunaan pendekatan kontekstual dalam proses pembelajaran sangat efektif untuk meningkatkan keaktifan dan motivasi siswa dalam mengikuti proses pembelajaran, serta efektif untuk meningkatkan hasil belajar siswa (Bakhri, Sari, \& Ernawati, 2019; Purwanto \& Rizki, 2015).

Ditinjau dari aspek media pembelajaran, multimedia interaktif berorientasi pendekatan kontekstual ini berada pada kualifikasi sangat baik. Perpaduan teks, gambar, suara, video, dan animasi sangat penting diperhatikan sebagai komponen sebuah media interaktif. Teks yang dipilih harus jelas dan mudah dibaca oleh siswa (Puspita, 2019; Rahmawati, Budiyono, \& Wardi, 2017). Kejelasan teks akan didukung oleh pemilihan warna dan ukuran teks yang tepat. Selain itu penyajian gambar dan animasi harus sesuai dengan karakteristik siswa sehingga dapat menari perhatian dan minat belajarnya (Kasih, 2017; Rosmiati, 2019). Suara yang termuat dalam multimedia sangat penting untuk membantu menjelaskan materi yang disampaikan (Siddiq, Sudarma, \& Simamora, 2020). Dengan adanya suara, siswa yang memiliki keterlambatan membaca teks akan terbantu, sehingga penyampaian materi menjadi efisien. Elemen-elemen seperti teks, gambar, suara, video, dan animasi yang ada di multimedia dapat menarik perhatian siswa (Surjono, 2017; Trianawati, 2019). Penyampaian materi pembelajaran melalui penggunaan multimedia interaktif yang didalamnya terdapat elemen-elemen seperti teks, gambar, suara, video dan animasi yang sesuai dengan materi efektif untuk memperjelas materi yang disampaikan dan dapat meningkatkan minat dan motivasi siswa dalam belajar. Temuan penelitian sebelumnnya juga menyatakan bahwa multimedia interaktif dapat membangkitkan semangat dan minat yang baru, membangkitkan motivasi, rangsangan belajar, membantu mempermudah proses belajar (Illahi, Sukartiningsih, \& Subroto, 2018; Mustaqim, 2016). Temuan penelitian lainnya juga menyatakan bahwa multimedia efektif untuk meningkatkan hasil belajar siswa (Prasetya et al, 2018; Sagala et al, 2017). Dapat disimpulkan bahwa multimedia interaktif dapat membantu siswa dalam belajar. Kelebihan media animasi yang dikembangkan. Kelebihan media yang dikembangkan yaitu multimedia ini juga menyajikan video animasi sehingga membuat siswa lebih termotivasi dalam belajar. Implikasi penelitian ini yaitu multimedia yang dikembangkan dapat digunakan oleh guru dalam proses pembelajaran sehingga dapat meningkatkan minat siswa dalam belajar terutama pada pembelajaran IPA.

\section{Simpulan}

Media multimedia interaktif berorientasi pendekatan kontekstual materi sumber energi pada pembelajaran mendapatkan kualifikasi sangat baik sehingga layak diterapkan dalam pembelajaran. Direkomendasikan kepada guru untuk menggunakan multimedia interaktif berorientasi pendekatan kontekstual karena dapat meningkatkan minat siswa dalam belajar, sehingga akan berpengaruh pada hasil belajar IPA meningkat.

\section{Daftar Rujukan}

Andrianingrum, F., \& Suparman. (2019). Design of interactive learning media based on contextual approach to improve problem-solving ability in fourth grade students. International Journal of Scientific and Technology Research, 8(11), 3906-3911.

Asmuni, A. (2020). Problematika Pembelajaran Daring di Masa Pandemi Covid-19 dan Solusi Pemecahannya. Jurnal Paedagogy, 7(4), 281. https://doi.org/10.33394/jp.v7i4.2941.

Bakhri, S., Sari, A. F., \& Ernawati, A. (2019). Kualitas Pembelajaran Kontekstual Siswa IPS Materi Program Linier yang Memiliki Kecemasan Belajar Matematika. Kreano Jurnal Matematika Kreatif-Inovatif, 10(2). https://doi.org/https://doi.org/10.15294/kreano.v10i2.19061.

Buchori, A. (2019). Pengembangan multimedia interaktif dengan pendekatan kontekstual untuk 
meningkatkan pemecahan masalah kemampuan matematika. Jurnal Inovasi Teknologi Pendidikan, 6(1), 104-115. https://doi.org/10.21831/jitp.v6i1.20094.

Campen, K., Carolien, Segers, E., \& Verhoeven, L. (2020). Effects of audio support on multimedia learning processes and outcomes in students with dyslexia. Computers and Education, 150(February), 103858. https://doi.org/10.1016/j.compedu.2020.103858.

Chang, T. Y., Hong, G., Paganelli, C., Phantumvanit, P., Chang, W. J., Shieh, Y. S., \& Hsu, M. L. (2020). Innovation of dental education during COVID-19 pandemic. Journal of Dental Sciences, 155. https://doi.org/10.1016/j.jds.2020.07.011.

Diputra, K. S. (2016). Pengembangan Multimedia Pembelajaran Tematik Integratif Untuk Siswa Kelas Iv Sekolah Dasar. JPI (Jurnal Pendidikan Indonesia), 5(2), 125. https://doi.org/10.23887/jpiundiksha.v5i2.8475.

Fitriyani, Y., Fauzi, I., \& Sari, M. Z. (2020). Motivasi Belajar Mahasiswa Pada Pembelajaran Daring Selama Pandemik Covid-19. Profesi Pendidikan Dasar, 7(1), 121-132. https://doi.org/10.23917/ppd.v7i1.10973.

Gitriani, Aisah, Hendriana, \& Herdiman. (2018). Pengembangan Lembar Kerja Siswa Berbasis Pendekatan Kontekstual pada Materi Lingkaran Untuk Siswa SMP. Jurnal Review Pembelajaran Matematika, 3(1). https://doi.org/https://doi.org/10.15642/jrpm.2018.3.1.40-48.

Hartini, A. (2017). Pengembangan Perangkat Pembelajaran Model Project Based Learning Untuk Meningkat Kemampuan Berpikir Kritis Siswa Sekolah Dasar. Jurnal Pendidikan Dan Pembelajaran Di Sekolah Dasar, 1(2). https://doi.org/http://dx.doi.org/10.30651/else.v1i2a.1038.

Heo, M., \& Toomey, N. (2020). Learning with multimedia: The effects of gender, type of multimedia learning resources, and spatial ability. Computers and Education, 146, 103747. https://doi.org/10.1016/j.compedu.2019.103747.

Herliandry, Enjelina, \& Kuswanto. (2020). Pembelajaran Pada Masa Pandemi Covid-19. Jurnal Teknologi Pendidikan, 22(1). Retrieved from https://doi.org/10.21009/jtp.v22i1.15286.

Hobri, Septiawati, I., \& Prihandoko, A. C. (2018). High-order thinking skill in contextual teaching and learning of mathematics based on lesson study for learning community. International Journal of Engineering and Technology(UAE), 7(3), 1576-1580. https://doi.org/10.14419/ijet.v7i3.12110.

Illahi, T. rahmah, Sukartiningsih, W., \& Subroto, W. T. (2018). Pengembangan Multimedia Interaktif pada Pembelajaran Materi Jenis-Jenis Pekerjaan Untuk Meningkatkan Kemampuan Berpikir Kritis. Jurnal Kajian Pendidikan Dan Hasil Penelitian, 4(3). https://doi.org/http://dx.doi.org/10.26740/jrpd.v4n3.p826-.

Irwanto, Taufik, Hernawan, \& Rizal. (2019). Efektivitas Multimedia Interaktif Dan Mobile Learning Dalam Meningkatkan Hasil Belajar Siswa Pada Mata Pelajaran Seni Budaya. Jurnal Pendidikan Dan Kajian Seni, 4(1). https://doi.org/http://dx.doi.org/10.30870/jpks.v4i1.6845.

Istiqlal, M. (2017). Pengembangan Multimedia Interaktif Dalam Pembelajaran Matematika. JIPMat, 2(1). https://doi.org/10.26877/jipmat.v2i1.1480.

Kasih, F. (2017). Pengembangan Film Animasi dalam Pembelajaran Fisika pada Materi Kesetimbangan Benda Tegar di SMA. Jurnal Keguruan Dan Ilmu Tarbiyah, 2(1), 41-47. https://doi.org/https://doi.org/10.24042/tadris.v2i1.1737.

Kurniawati, N. M. E., Sudana, D. N., \& Mahadewi, L. P. P. (2013). Pengaruh Model Pembelajaran Reciprocal Teaching Terhadap Penguasaan Konsep IPA Siswa Kelas V Sd Gugus I Kecamatan Buleleng. Mimbar PGSD Undiksha, 1(1). https://doi.org/http://dx.doi.org/10.23887/jjpgsd.v1i1.1358.

Latief, H. (2014). Pengaruh Pembelajaran Kontekstual Terhadap Hasil Belajar (Studi Eksperimen Pada Mata Pelajaran Geografi Kelas VII DI SMPN 4 Padalarang. Jurnal Geografi, 14(2). https://doi.org/https://doi.org/10.17509/gea.v14i2.3395.

Lestari, K. P., Putra, D. K. N. S., \& Negara, I. G. A. O. (2018). Pengaruh Model Discovery Learning Berbantuan Media Audio Visual dalam Setting Lesson Study Terhadap Hasil Belajar IPA Mahasiswa PGSD Undiksha UPP Denpasar Tahun 2017. Jurnal Ilmiah Sekolah Dasar, 2(1), 40-45. https://doi.org/http://dx.doi.org/10.23887/jisd.v2i1.13898.

Maria, U., Rusilowati, A., \& Hardyanto, W. (2019). Interactive Multimedia Development in The Learning Process of Indonesian Culture Introduction Theme for 5-6 Year Old Children. Journal of Primary Education, 8(3), 344-353.

Mariyaningsih, N. (2012). Penerapan Metode Kontekstual Investigasi Bisnis Dan Game Ular Tangga Kombi Dalam Upaya Meningkatkan Aktivitas Dan Hasil Belajar Komunikasi Bisnis. Dinamika Pendidikan, 7(2). https://doi.org/https://doi.org/10.15294/dp.v7i2.4908.

Maunah, B. (2015). Implementasi Pendidikan Karakter dalam Pembentukan Kepribadian Holistik Siswa. Jurnal Pendidikan Karakter, 1(1). https://doi.org/https://doi.org/10.21831/jpk.v0i1.8615.

Mawarni, \& Muhtadi. (2017). Pengembangan Buku Digital Interaktif Mata kuliah Pengembangan 
Multimedia Pembelajaran Interaktif Untuk Mahasiswa Teknologi Pendidikan. Jurnal Inovasi Teknologi Pendidikan, 4(1). https://doi.org/https://doi.org/10.21831/jitp.v4i1.10114.

Mustaqim, I. (2016). Multimedia services on top of M3 Smart Spaces. Jurnal Pendidikan Teknologi Dan Kejuruan, 13(2), 174. http://dx.doi.org/10.23887/jptk-undiksha.v13i2.8525.

Mustika, D., \& Ain, S. Q. (2020). Peningkatan Kreativitas Mahasiswa Menggunakan Model Project Based Learning dalam Pembuatan Media IPA Berbentuk Pop Up Book. Jurnal Basicedu, 4(4), 1167-1175. https://doi.org/https://doi.org/10.31004/basicedu.v4i4.518.

Mustikaningrum, G., Pramusinta, L., Ayu, S., \& Umar, M. (2020). Implementasi Pendidikan Karakter Terintegrasi Kurikulum Dan Metode Pembelajaran Pada Masa Pandemi Covid-19. AULADUNA: $\begin{array}{llll}\text { Jurnal Pendidikan Islam, } & \text { 7(2), }\end{array}$ https://doi.org/https://doi.org/10.24252/10.24252/auladuna.v7i2a5.2020.

Nataliani, N. W., Jampel, I. N., \& Suartama, I. K. (2014). Pengembangan Multimedia Pembelajaran Mata Pelajaran IPS Kelas VII Semester Genap di SMP Negeri 2 Tegallalang. Journal Edutech Universitas Pendidikan Ganesha, 2(1), 1-12.

Nilasari, Djatmika, T., \& Santoso. (2016). Pengaruh Penggunaan Modul Pembelajaran Kontekstual terhadap Hasil Belajar Siswa Kelas V Sekolah Dasa. Jurnal Pendidikan: Teori, Penelitian, Dan Pengembangan, 7(1), 1399-1404. https://doi.org/https://doi.org/10.17977/jp.v1i7.6583.

Permana, E. P., \& Nourmavita, D. (2017). Pengembangan Multimedia Interaktif Pada Mata Pelajaran Ipa Materi Mendeskripsikan Daur Hidup Hewan Di Lingkungan Sekitar Siswa Kelas Iv Sekolah Dasar. Jurnal PGSD, 10(2), 79-85. https://doi.org/10.33369/pgsd.10.2.79-85.

Prasetya, Ade Yama Wahyu Nur, D. K., \& Akbar, S. (2018). Multimedia Interaktif pada Pembelajaran Tematik untuk Kelas IV Sekolah Dasar. Jurnal Pendidikan: Teori, Penelitian, Dan Pengembangan, 3(11), 1423-1427. https://doi.org/http://dx.doi.org/10.17977/jptpp.v3i11.11751.

Pravitasari, S. G., \& Yulianto, M. L. (2018). Penggunaan Multimedia Interaktif Dalam Pembelajaran Bahasa Inggris (Studi Kasus Di Sdn 3 Tarubasan Klaten). Profesi Pendidikan Dasar, 1(1), 37. https://doi.org/10.23917/ppd.v1i1.3825.

Prayito. (2011). Pengembangan Perangkat Pembelajaran Matematika Humanistik Berbasis Konstruktivisme Berbantuan E-Learning Materi Segitiga Kelas VII. AKSIOMA Journal of Mathematics Education, 2(2). https://doi.org/https://doi.org/10.26877/aks.v2i2/Septembe.37.

Purwanto, Y., \& Rizki, S. (2015). Pengembangan Bahan Ajar Berbasis Kontekstual Pada Materi Himpunan Berbantu Video Pembelajaran. AKSIOMA Journal of Mathematics Education, 4(1), 67-77. https://doi.org/10.24127/ajpm.v4i1.95.

Puryadi, P., Rahayu, S., \& Sutrio, S. (2018). Pengaruh Model Pembelajaran Direct Instruction Berbantuan Bahan Ajar Berbasis Kontekstual Terhadap Hasil Belajar IPA Terapan Siswa Kelas X SMKN 4 Mataram Tahun Ajaran 2015/2016. Jurnal Pendidikan Fisika Dan Teknologi, 4(1). https://doi.org/https://doi.org/10.29303/jpft.v4i1.329.

Puspita, L. (2019). Pengembangan Modul Berbasis Keterampilan Proses Sains Sebagai Bahan Ajar Dalam Pembelajaran Biologi. Jurnal Inovasi Pendidikan IPA, 5(1), 79-87. https://doi.org/https://doi.org/10.21831/jipi.v5i1.22530.

Qazi, A., Qazi, J., Naseer, K., Zeeshan, M., Qazi, S., Abayomi-alli, O., ... Haruna, K. (2021). Adaption of Distance Learning to Continue the Academic Year Amid COVID-19 Lockdown. Journal Pre-Proofs (Children and Youth Services Review), 1-20. https://doi.org/10.1016/j.childyouth.2021.106038.

Rahmawati, Budiyono, \& Wardi. (2017). Pengembangan Modul Pembelajaran Digital Berbasis Visual Basic for Application (VBA) PowerPoint. Indonesian Journal of Curriculum and Educational Technology, 5(1). https://doi.org/https://doi.org/10.15294/ijcets.v5i1.14248.

Rahmawati, E., Irdamurni, I., \& Amini, R. (2019). Pengembangan Modul Berbasis Pendekatan Kontekstual Dengan Adobe Flash Untuk Siswa Sekolah Dasar. Jurnal Basicedu, 3(2). https://doi.org/https://doi.org/10.31004/basicedu.v3i2.29.

Ratih, i K. D. R., Japa, I. G. N., \& Margunayasa, I. G. (2017). Pengaruh Model Pembelajaran Numbered Head Together Berbantuan Multimedia Interaktif Terhadap Hasil Belajar IPA. MIMBAR PGSD Undiksha, 5(2), 1-9. https://doi.org/http://dx.doi.org/10.23887/jjpgsd.v5i2.10880.

Rosmiati, M. (2019). Animasi Interaktif Sebagai Media Pembelajaran Bahasa Inggris Menggunakan Metode ADDIE. Paradigma: Jurnal Komputer Dan Informatika Univiersitas Bina Sarana Informatika, 21(2). https://doi.org/https://doi.org/10.31294/p.v21i2.6019.

Sagala, G., Mesran, M., Sutiksno, D. U., Yuhandri, Y., \& Suginam, S. (2017). Perancangan Aplikasi Pembelajaran Pakaian Adat Asli Indonesia Berbasis Multimedia Dan Web Menerapkan Metode Computer Assisted Instruction (Cai). JURIKOM (Jurnal Riset Komputer), 4(4). https://doi.org/http://dx.doi.org/10.30865/jurikom.v4i4.711.

Santoso, E. (2017). Penggunaan Model Pembelajaran Kontekstual Untuk Meningkatkan Kemampuan 
Pemahaman Matematika Siswa Sekolah Dasar. Jurnal Cakrawala Pendas, 3(1). https://doi.org/http://dx.doi.org/10.31949/jcp.v3i1.407.

Saselah, Y. R., M, M. A., \& Qadar, R. (2017). Pengembangan Multimedia Interaktif Berbasis Adobe Flash CS6 Professional Pada Pembelajaran Kesetimbangan Kimia. Jurnal Kimia Dan Pembelajaran Kimia, 2(2), 80-89.

Siddiq, Sudarma, \& Simamora. (2020). Pengembangan Animasi Dua Dimensi Pada Pembelajaran Tematik Untuk Siswa Kelas III Sekolah Dasar. Jurnal Edutech Undiksha, 8(2), 49-63. https://doi.org/http://dx.doi.org/10.23887/jeu.v8i2.28928.

Surjono, H. D. (2017). Multimedia Pembelajaran Interaktif Konsep dan Pengembangan. Yogyakarta: UNY Press.

Surjono, J. (2016). Pengembangan Multimedia Pembelajaran Bahasa Inggris Untuk Pembelajaran Teks Recount Di Mtsn II Yogyakarta. Jurnal Inovasi Teknologi Pendidikan, 3(1), 25-39. https://doi.org/https://doi.org/10.21831/tp.v3i1.8287.

Towoliu, I. D., Hartati, S., \& Hapidin, H. (2020). Pendidikan Karakter Berbasis Islam melalui Program Cinta Rosul pada Anak Taman Kanak-Kanak. Jurnal Obsesi : Jurnal Pendidikan Anak Usia Dini, 5(1). https://doi.org/https://doi.org/10.31004/obsesi.v5i1.618.

Trianawati. (2019). Pengaruh Model Discovery Learning Berbantuan Media Animasi Terhadap Kompetensi Pengetahuan IPA Siswa Kelas IV SDN Gugus VI Abiansemal Tahun Ajaran 2018/2019. $\begin{array}{llll}\text { International Journal of Elementary } & \text { Education, }\end{array}$ https://doi.org/http://dx.doi.org/10.23887/ijee.v4i1.24337.

Umbara, I. A. A. P., Sujana, I. W., \& Negara, I. G. A. O. (2020). Model Pembelajaran Problem Based Learning Berbantuan Media Gambar Seri BerpengaruhTerhadap Kompetensi Pengetahuan IPS Siswa. Jurnal Mimbar Ilmu, 25(2), 13-25. https://doi.org/http://dx.doi.org/10.23887/mi.v25i2.25154.

Wulandari, R., Susilo, H., \& Kuswandi, D. (2017). Penggunaan Multimedia Interaktif Bermuatan Game Edukasi untuk Meningkatkan Aktivitas dan Hasil Belajar Siswa Sekolah Dasar. Jurnal Pendidikan: Teori, Penelitian Dan Pengembangan, 2(8), 1024-1029.

Yuniarni, Sari, \& Atiq. (2020). Pengembangan Multimedia Interaktif Video Senam Animasi Berbasis Budaya Khas Kalimantan Barat. Jurnal Obsesi: Jurnal Pendidikan Anak Usia Dini, 4(1). https://doi.org/https://doi.org/10.31004/obsesi.v4i1.331. 